RUSSIAN

I WILD

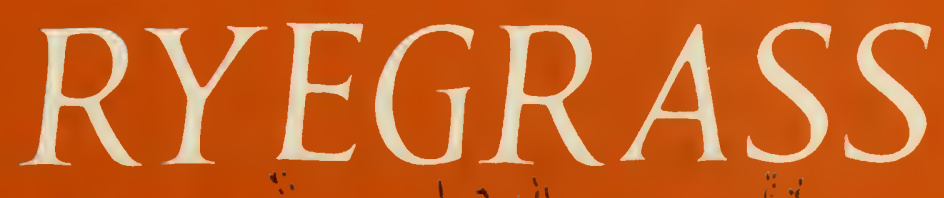

for Western Canada

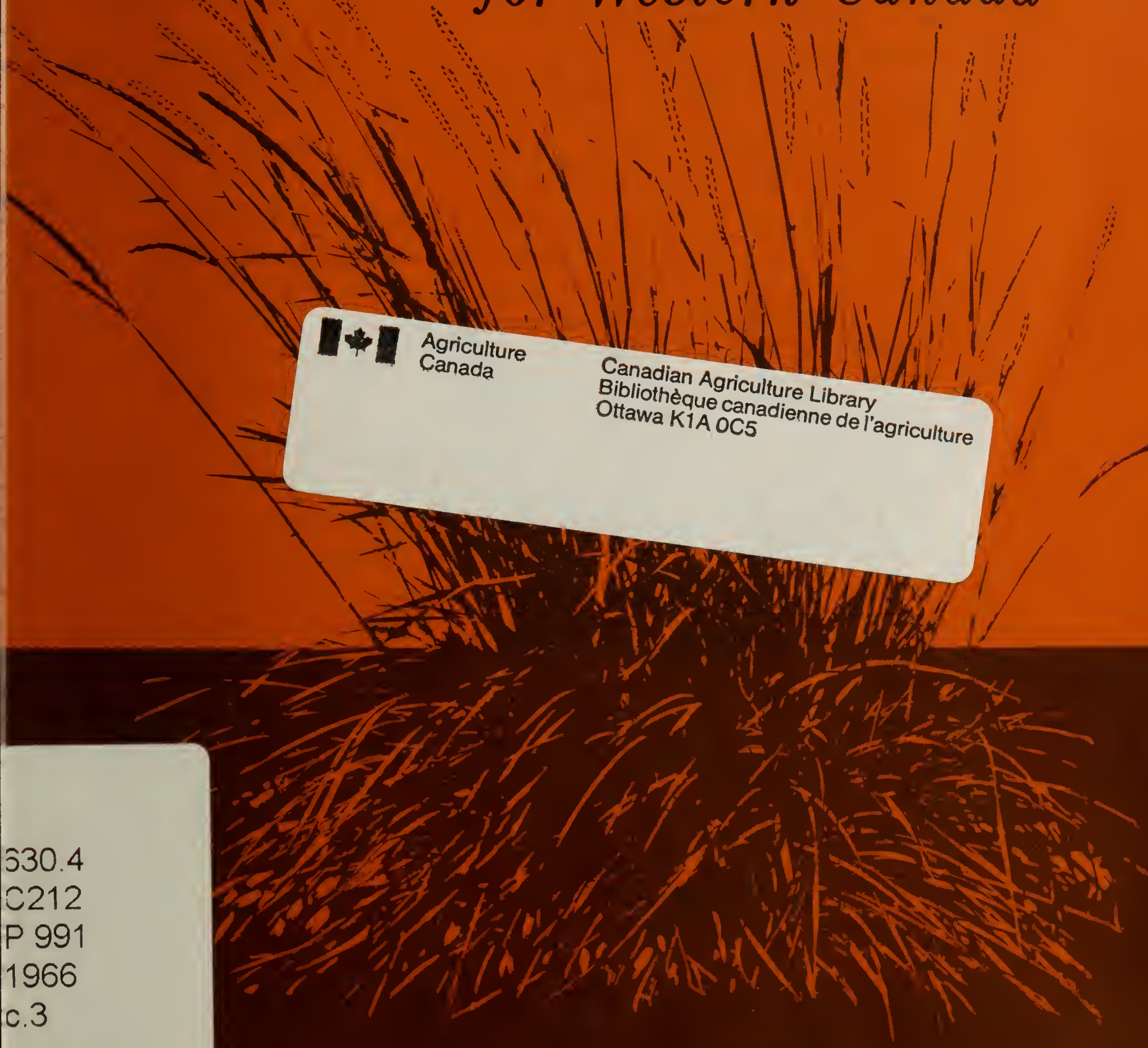




\section{A PASTURE GRASS FOR DRY AREAS}

Russian wild ryegrass is especially useful for pasture in the dry prairies and the semiarid interior of British Columbia. This grass is a long-lived perennial bunchgrass with extensive fibrous roots. It is exceptionally resistant to cold and drought. Russian wild ryegrass is the only cultivated grass that cures well on the stem and retains its nutritive value in the summer and late fall. Livestock pastured on this grass make good gains even in the fall when they tend to lose weight on most other grasses. Russian wild ryegrass is one of the best for farmyards and lawns that cannot be watered.

If you are going to use Russian wild ry egrass, remember:

- Sawki is the recommended variety.

- For pasture, seed in the spring in a well-prepared seedbed, or in the late fall into clean stubble, at 5 to 6 pounds per acre and $1 / 2$ to 1 inch deep. In dry areas, space the rows 12 to 18 inches apart; in more moist areas, 6 to 12 inches apart. For a seed crop, drill in rows 36 inches apart at 2 to 3 pounds per acre.

- Seed a legume with Russian wild ryegrass wherever possible. Rambler alfalfa is recommended.

- For farmyards and lawns, broadcast or drill the seed at a heavy rate on a well-prepared seedbed.

- When grown for seed, Russian wild ryegrass makes an ideal dual-purpose crop as the aftermath provides a nutritious, palatable pasture for late summer and fall.

- Seed yields may be maintained at a high level for several years by fertilizing, removing the aftermath, and irrigating in in dry years.

- Harvest for seed when the straw is golden yellow and the seed is in the late milk to firm dough stage. Swathing and threshing the seed later with a combined is recommended. 


\section{CONTENTS}

Adaptation............................ 5

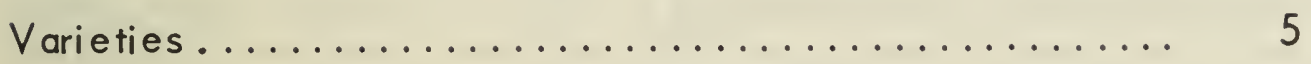

Seeding and $L$ and Preparation .................. 5

Uses and Management..................... 6

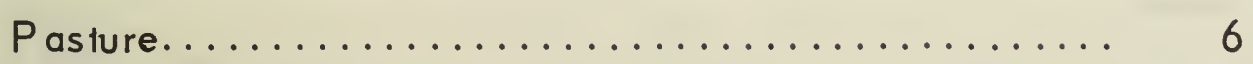

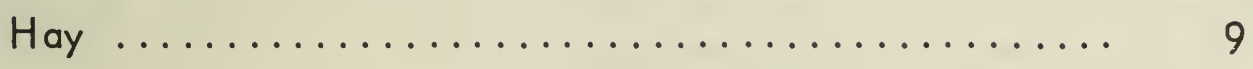

Farmyards and Lawns.................... 11

Seed Production ........................ 11

Seeding $\ldots \ldots \ldots \ldots \ldots \ldots \ldots \ldots \ldots \ldots \ldots \ldots \ldots \ldots \ldots$

Fertilizing $\ldots \ldots \ldots \ldots \ldots \ldots \ldots \ldots \ldots \ldots \ldots \ldots \ldots \ldots \ldots$

Irrigating $\ldots \ldots \ldots \ldots \ldots \ldots \ldots \ldots \ldots \ldots \ldots \ldots \ldots \ldots$

Aftermath $\ldots \ldots \ldots \ldots \ldots \ldots \ldots \ldots \ldots \ldots \ldots \ldots \ldots \ldots$

Harvesting ...................... 15

Cleaning $\ldots \ldots \ldots \ldots \ldots \ldots \ldots \ldots \ldots \ldots \ldots \ldots \ldots \ldots \ldots \ldots$

Marketing........................ 16

Other Helpful Information ................. 17 


\title{
RUSSIAN WILD RYEGRASS for Western Canada
}

\author{
T. Lawrence and D.H. Heinrichs \\ Experimental Farm, Swift Current, Sask.
}

Russian wild ryegrass (Elymus junceus Fisch.) was introduced from Siberia by the University of Saskatchewan in 1926. It was first grown at the Experimental Farm, Swift Current, in 1936, and was distributed from there to seed growers in Western Canada in 1949. It is an excellent pasture grass for the southern areas of the Canadian prairies. Its good curing qualities make it especially useful for late summer and fall grazing. The aftermath from seed production fields is nutritious and can be used for late summer and fall pasture.

Russian wild ryegrass is a long-lived perennial bunchgrass with extensive fibrous roots. It is very resistant to cold and drought. Seedlings grow slower than those of crested wheatgrass and consequently it is more difficult to establish. Once established, howiever, it is more persistent than crested wheatgrass (Figure 1). The leaves of Russian wild ryegrass are mostly basal; a few grow on the seedstalks. Seedstalks seldom form when the grass is grown in solid seedings, but when it is grown in spaced rows they are from 2 to 4 feet tall.

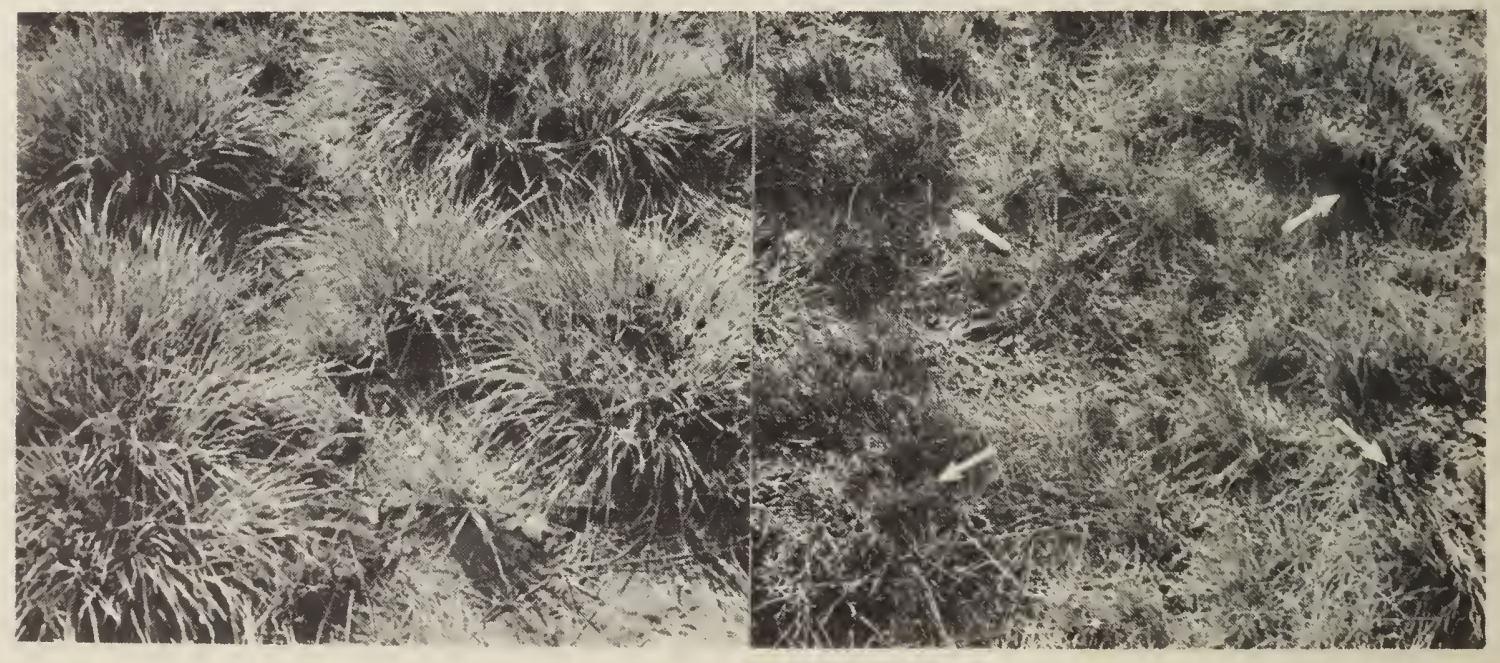

Figure l - Russian wild ryegrass plants (left) in a nursey were still intact 14 years after planting. Crested wheatgrass plants (right) were dying from the centers of the clumps (arrows).

The head is a dense spike with seeds that shatter readily at maturity. The seed is similar in size and shape to that of Summit or Nordan crested wheatgrass but is slightly pubescent, and its tip is blunter. 


\section{ADAPTATION}

Russian wild ryegrass grows wild in southeastern Siberia, Russia and central Asia. Russian authorities describe its habitat as steppes and steppe slopes.

In Canada, Russian wild ryegrass is well adapted to the loam and clay soils of the prairies of Saskatchewan, Alberta, and Manitoba and the semiarid interior of British Columbia. It is difficult to establish on sandy soils in dry areas because the seedlings grow slowly and do not get rooted deep enough before the surface soil dries out. Once established, however, it does well on sandy soils. Also, this grass tolerates saline soil rather well.

\section{VARIETIES}

Sawki, is the only variety licensed for sale in Canada. It produces more seed and slightly more forage than commercial strains. It was developed at the Experimental Farm, Swift Current and released in January 1963.

Vinall, developed at Mandan, North Dakota, by the United States Department of Agriculture, is recommended in the United States. In Canada it is not superior to Sawki.

\section{SEEDING AND LAND PREPARATION}

Spring seeding is preferable to fall seeding. Firm the seedbed to ensure shallow seeding. Depth controls attached to the drill discs help to seed at
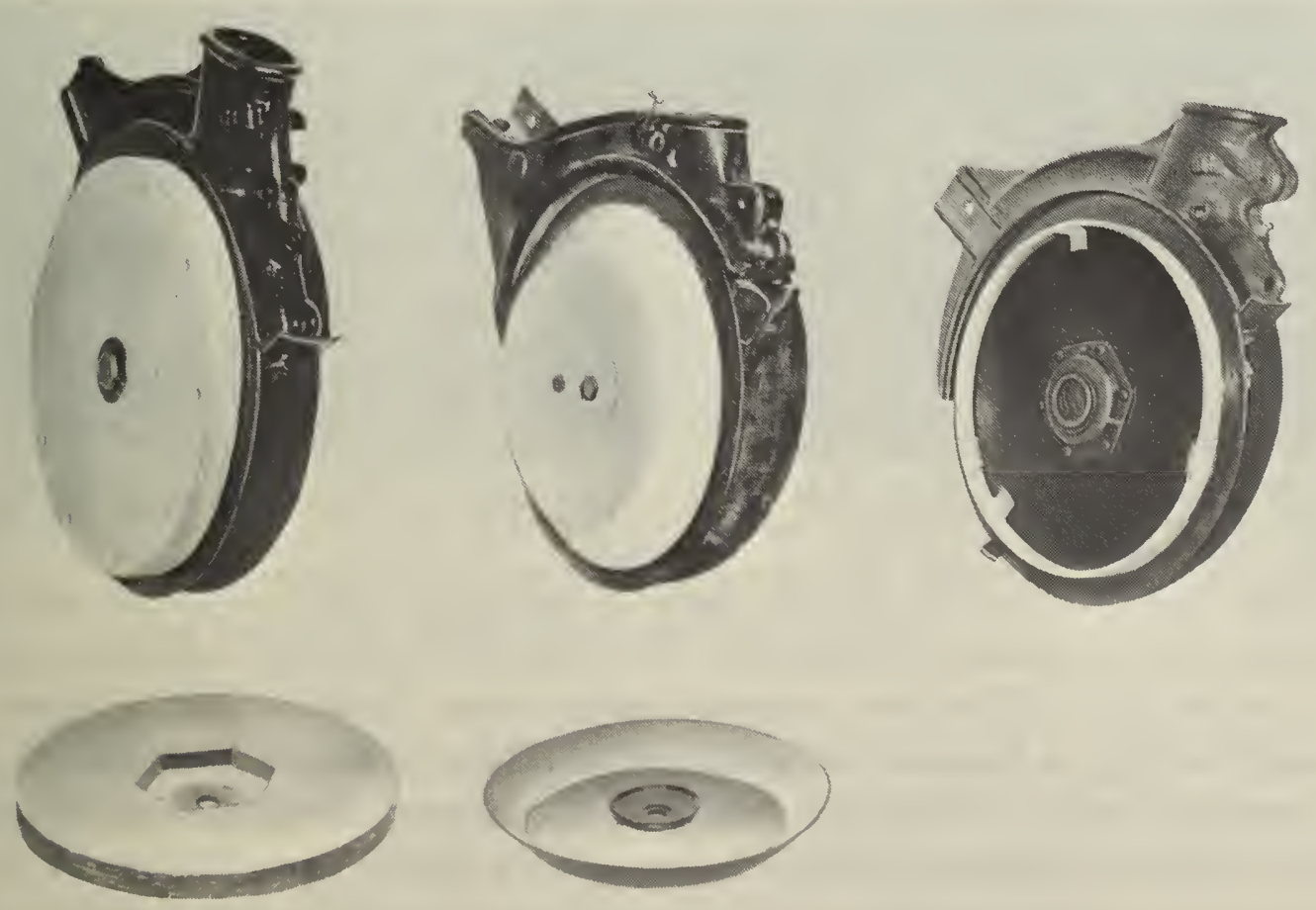

Figure 2 - Attachments for drill discs to control depth of seeding. Left to right: a plywood type to be clamped on the disc, a commercial pie plate clamp-on type, and a flange ring spot welded to the disc. 
a uniformly shallow depth of less than one inch (Figure 2). Because Russian wild ryegrass seedlings develop slowly, destroy weeds before seeding either by cultivation or with herbicides. You may use additional chemical weed control after the grass has developed beyond the three-leaf stage.

When fall seeding is necessary wait until after mid-October and sow into clean stubble without cultivation. The stubble will trap snow and ensure a moisture supply for germination early in the spring.

For pasture in the semiarid regions, seed Russian wild ryegrass in rows 12 or 18 inches apart at 5 to 6 pounds per acre, together with 1 pound of Rambler alfalfa. In more moist areas, you may increase the rate to 8 pounds per acre and seed in rows 6 or 7 inches apart.

For seed production seed Russian wild ryegrass in rows 3 feet apart at 2 to $2 \frac{1}{2}$ pounds per acre.

\section{USES AND MANAGEMENT}

\section{Pasture}

Russian wild ryegrass is valuable for pasture when grown alone or in a mixture with alfalfa. In tests on five experimental farms in the Prairie Provinces the average yield of Russian wild ryegrass was about the same as that of crested wheatgrass, but it contained more protein. The comparative yields in pounds per acre were:

Russian wild ryegrass

Crested wheatgrass
Dry matter

2,516

$2,4,49$
Protein

374

342

Cattle and sheep prefer Russian wild ryegrass to bromegrass or crested wheatgrass, and therefore it is best not to grow them together in mixture or in one enclosure.

In an experiment with 2-acre plots at Tugaske, Saskatchewan, cattle ate Russian wild ryegrass in preference to crested wheatgrass and brome grass. The percentages of various grasses eaten were: Russian wild ryegrass 90 , bromegrass 70 , and crested wheatgrass 55 . This preference held throughout the season during different years, and at a heavy stocking rate. On three Saskatchewan farms at Swift Current, Maple Creek, and Radisson, where pure stands of bromegrass, crested wheatgrass, and Russian wild ryegrass were grown in the same enclosures, the animals grazed the Russian wild ryegrass to the ground but grazed the other grasses sparingly. 
Russian wild ryegrass recovers rapidly after grazing when moisture is adequate (Figure 3). At Outlook, Saskatchewan, the second cutting of Russian wild ryegrass yielded considerably more than the second cuttings of either crested wheatgrass or bromegrass. The dry matter yields in tons per acre from the three grasses grown along and in mixture with alfalfa were:

\begin{tabular}{lcccccc} 
& \multicolumn{3}{c}{ Alone } & \multicolumn{4}{c}{ With alfalfa } \\
Grass & Cut 1 & Cut 2 & Total & Cut 1 & Cut 2 & Total \\
an wild ryegrass & 1.27 & 0.76 & 2.03 & 1.28 & 1.73 & 3.00 \\
ay crested wheat- & & & & & & \\
grass & 1.35 & 0.44 & 1.79 & 1.40 & 1.59 & 2.99 \\
& 1.37 & 0.34 & 1.71 & 1.92 & 1.26 & 3.18
\end{tabular}

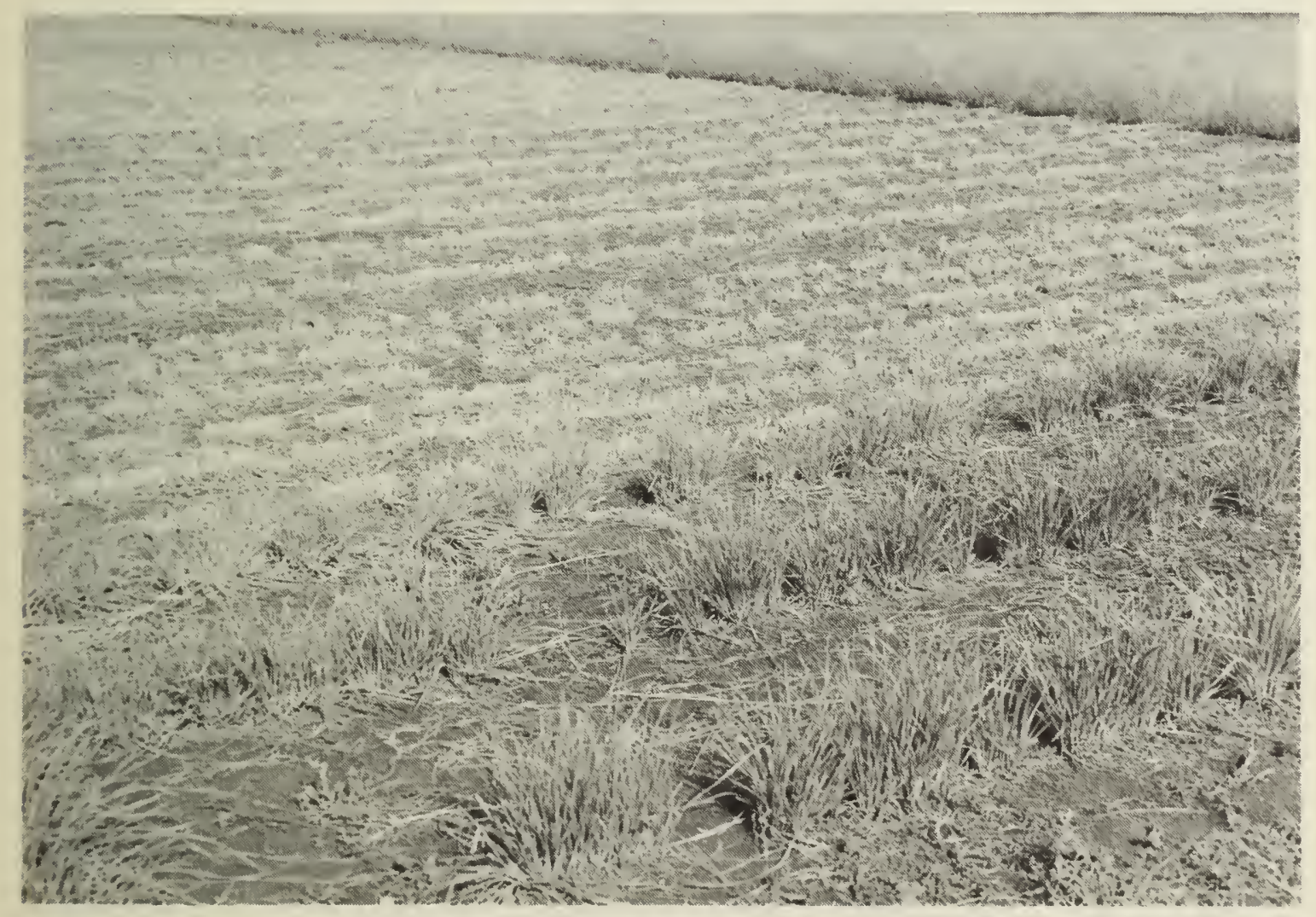

Figure 3 - Russian wild ryegrass (foreground) resumes growth much better after cutting than crested wheatgrass (background). The photo was taken one week after cutting in June.

In a grazing trial at Swift Current sheep were used to graze Russian wild ryegrass-alfalfa and crested wheatgrass-alfalfa pastures continuously throughout the season. Pasture production, consumption, and carrying capacity were similar for the two mixtures, but liveweight gains per ewe and per acre were about 50 percent greater for the Russian wild ryegrass pasture whereas consumption per pound of gain was considerably less. 
The 4-year average gains and yields from the Kussian wild ryegrassalfalfa and crested wheatgrass-alfalfa pastures, on dryland, grazed at the rate of two yearling ewes per acre for $5 \frac{1}{2}$ months, were:

\begin{tabular}{|c|c|c|c|c|c|}
\hline Mixture & $\begin{array}{l}\text { Dry matter } \\
\text { lb. per acre }\end{array}$ & $\begin{array}{l}\text { Pounds eaten } \\
\text { per ewe } \\
\text { daily }\end{array}$ & $\begin{array}{l}\text { Animal } \\
\text { Per } \\
\text { ewe }\end{array}$ & $\begin{array}{r}\text { gains, } \\
\text { Per } \\
\text { acre }\end{array}$ & $\begin{array}{l}\text { Pounds } \\
\text { lb. eaten } \\
\text { per pound } \\
\text { gained }\end{array}$ \\
\hline $\begin{array}{l}\text { Russian wild } \\
\text { yegrass and } \\
\text { alfalfa }\end{array}$ & 1,210 & 3.0 & 24 & 50 & 21 \\
\hline $\begin{array}{l}\text { ested } \\
\text { eatgrass and }\end{array}$ & 1,160 & 2.8 & 14 & 35 & 26 \\
\hline
\end{tabular}
alfalfa

Liveweight gains of sheep were greater on Russian wild ryegrass and alfalfa after July than on crested wheatgrass and alfalfa (Figure 4). After September 1, animals on the Russian wild ryegrass-alfalfa mixture continued to gain weight, whereas those on the crested wheatgrass-alfalfa mixture started to lose. The excellent gains on the Russian wild ryegrassalfalfa mixture were attributed to a higher nutritive value and a slightly greater daily intake. Comparable results have been obtained from grazing tests at Manyberries, Alberta.

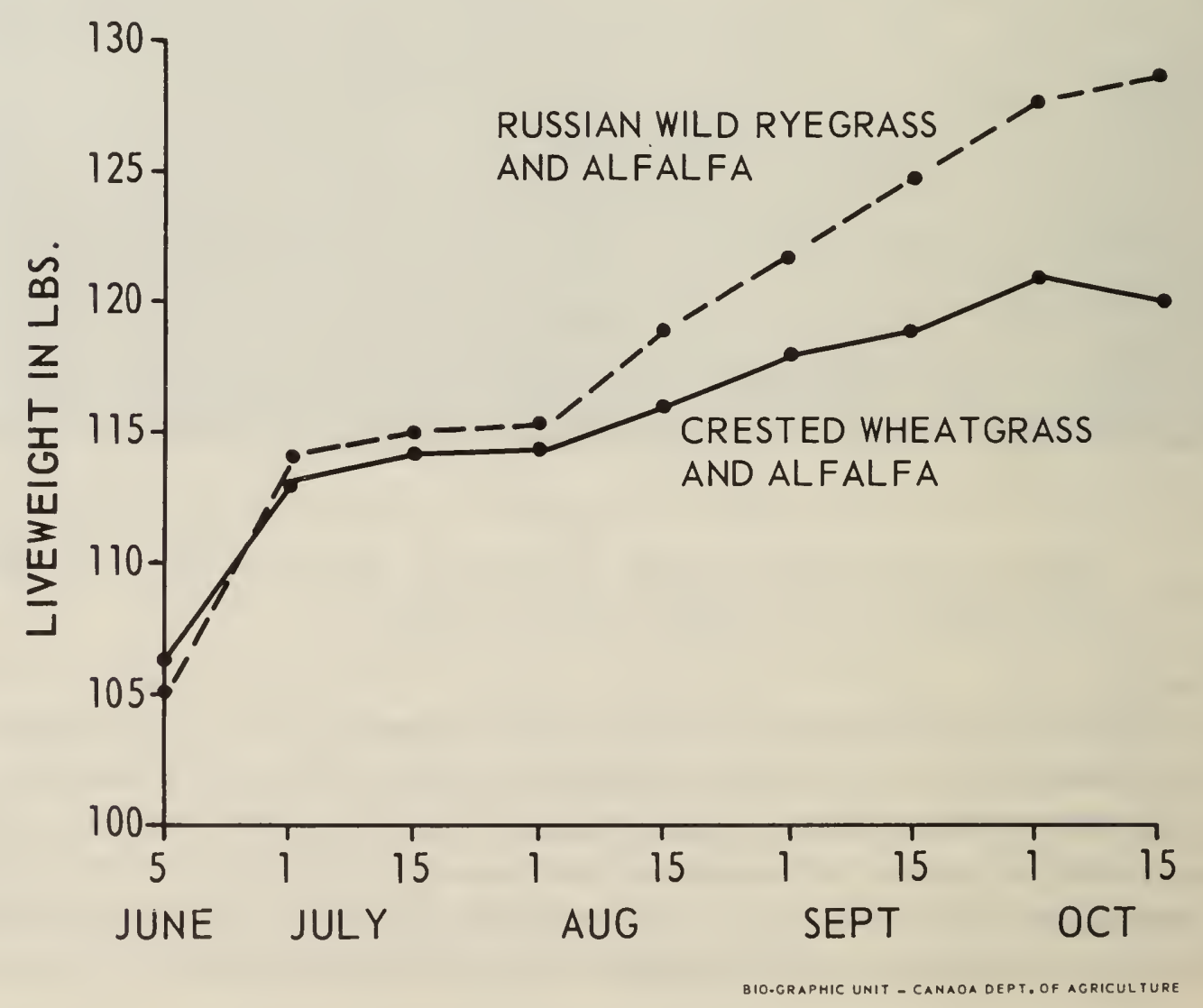

Figure 4 - Four-year average weight of 70 yearling ewes while grazing on Russian wild ryegrass-alfalfa and crested wheatgrass-alfalfa pasture from date following shearing to end of grazing season. 
The value of Russian wild ryegrass as a well-balanced pasture feed for late summer and fall is also shown by the chemical composition (Table 1). It contains more protein than either crested wheatgrass or bromegrass after the shot-blade stage, and after the mature seed stage its protein content is twice that of crested wheatgrass. Its fat content, important in providing calories late in the fall, is higher than for crested wheatgrass or bromegrass. Russian wild ryegrass contains less carbohydrate than either bromegrass or crested wheatgrass, but is similar in ash and crude fiber content.

\section{Table 1. Chemical Compositions of Three Pasture Grasses at Progressive Stages of Development}

(Average percentages of various constituents in a 2-year test)

\begin{tabular}{|c|c|c|c|c|c|c|c|}
\hline Constituents & Grass & $\begin{array}{l}\text { Early } \\
\text { leaf }\end{array}$ & $\begin{array}{l}\text { Shot- } \\
\text { blade }\end{array}$ & Flower & $\begin{array}{c}\text { Mature } \\
\text { seed }\end{array}$ & $\begin{array}{l}\text { Late } \\
\text { fall }\end{array}$ & $\begin{array}{l}\text { Next } \\
\text { spring }\end{array}$ \\
\hline \multirow[t]{3}{*}{ Crude protein } & Russian wild ryegrass & 21.1 & 16.4 & 11.5 & 9.4 & 7.3 & \\
\hline & Crested wheatgrass & 20.1 & $14 \cdot 2$ & 6.4 & $5 \cdot 4$ & 3.1 & \\
\hline & Bromegrass & 20.7 & 17.1 & 10.4 & 7.3 & 4.5 & \\
\hline Carbohydrates & Russian wild ryegrass & 42.9 & 46.6 & 46.3 & 44.9 & 45.7 & \\
\hline
\end{tabular}

(Nitrogen-free extract)

$\begin{array}{lllllll}\text { Crested whe atgrass } & 44.7 & 49.8 & 55.0 & 55.7 & 49.7 & 47.9 \\ \text { Bromegrass } & 43.9 & 46.5 & 53.1 & 54.3 & 49.9 & 48.3\end{array}$

\begin{tabular}{llrrrrrr} 
Fat & Russian wild ryegrass & 1.7 & 1.6 & 1.4 & 1.7 & 1.6 & 1.2 \\
(Ether extract) & Crested wheatgrass & 2.2 & 1.7 & 1.4 & 1.7 & 1.1 & 0.7 \\
& Bromegrass & 2.3 & 2.0 & 1.5 & 1.8 & 1.4 & 1.0 \\
& & & & & & & \\
\multirow{2}{*}{ Ash } & Russian wild ryegrass & 10.2 & 8.9 & 8.0 & 9.2 & 7.5 & 8.6 \\
& Crested wheatgrass & 9.0 & 7.8 & 6.0 & 6.7 & 7.3 & 7.8 \\
& Bromegrass & 10.6 & 10.0 & 6.8 & 8.0 & 7.8 & 9.3
\end{tabular}

$\begin{array}{llllllll}\text { Crude fiber } & \text { Russian wild ryegrass } & 24.0 & 26.5 & 32.8 & 34.7 & 37.9 & 38.8 \\ & \text { Crested whe atgrass } & 24.0 & 26.4 & 31.1 & 30.6 & 38.8 & 40.3 \\ & \text { Bromegrass } & 22.4 & 24.4 & 28.2 & 28.5 & 36.4 & 37.0\end{array}$

\section{Hay}

Russian wild ryegrass should not be seeded for hay. It generally yields less than either crested wheatgrass or bromegrass when grown alone or with alfalfa. The average hay yields for Russian wild ryegrass, crested wheatgrass, and bromegrass grown alone and with alfalfa in a number of tests, on a range of soil types, and over several years were: 
Grass

Russian wild ryegrass

Crested wheatgrass

Bromegrass
Dry matter yield in tons per acre Alone

With alfalfa

In all hay tests Russian wild ryegrass persisted well and resisted invasion by weeds and other grasses. In a study of competition between grasses, in several trials where Russian wild ryegrass was grown in mixture with other grasses at Swift Current, it was the only one that competed favorably with crested wheatgrass.

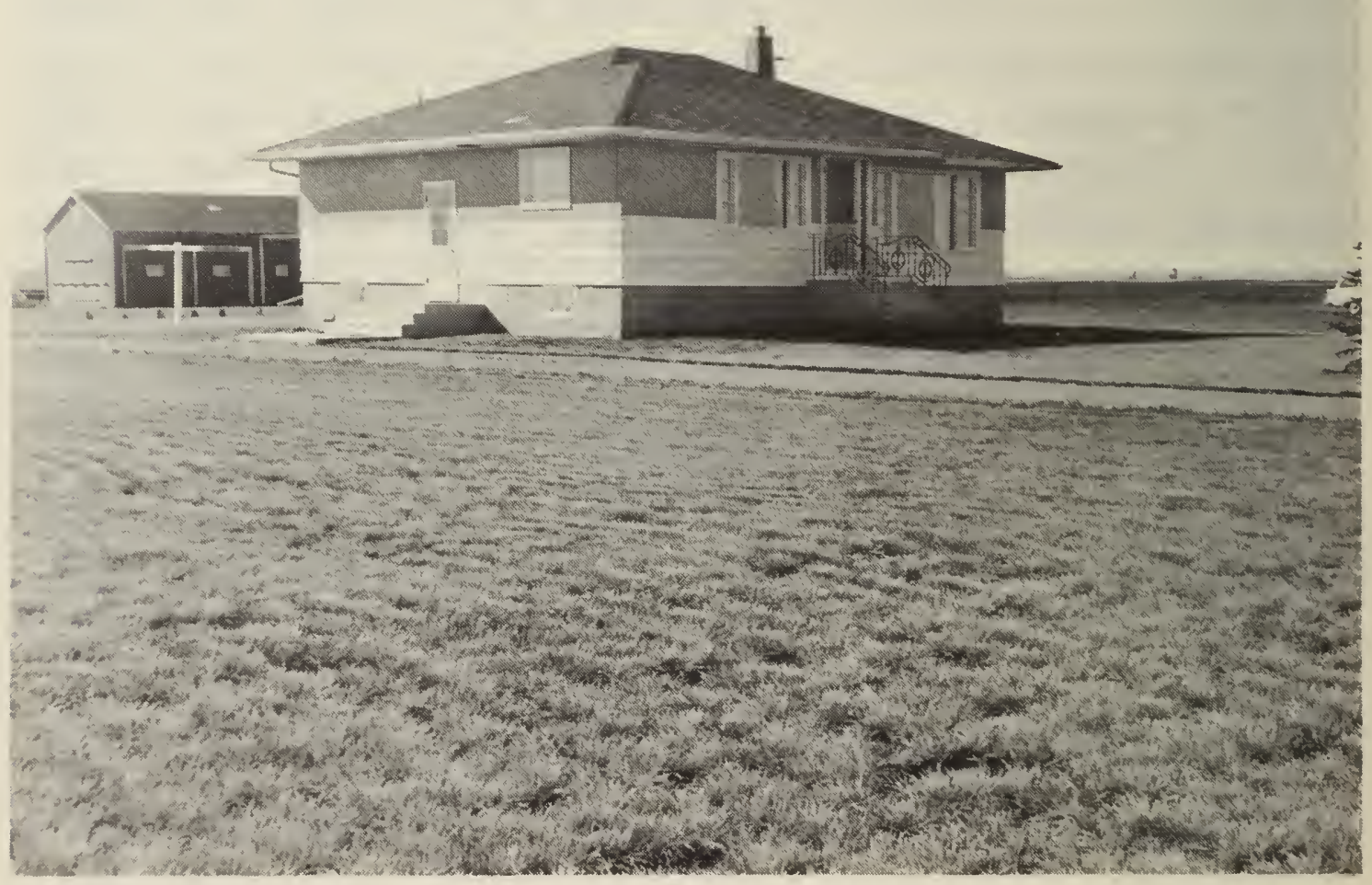

Figure 5 - A modern farmyard and lawn sown to Russian wild ryegrass. 


\section{Farmyards and Lawns}

Russian wild ryegrass is one of the best grasses for farmyards and lawns that cannot be watered (Figure 5). It is leafy, seldom forms stems, and remains green for most of the summer. It recovers quicker after cutting than crested wheatgrass, and because it seldom heads out, does not invade trees and hedges like crested wheatgrass. The sod formed by Russian wild ryegrass is extremely tough and stands considerable abuse from tramping and driving. In tests at Saskatoon and Indian Head, Saskatchewan, it has been more durable than crested wheatgrass.

For lawns and small yards broadcast Russian wild ryegrass by hand or with a small cyclone seeder at 3 to 4 pounds of seed per 1,000 square feet. Prepare the seedbed and rake or harrow it before and after seeding to firm the soil and cover the seed.

For large areas use a drill. Set the drill at about 15 pounds of seed per acre ( 1 bushel wheat drill setting) and seed the area in at least two directions at right angles to one another.

Be sure to protect the newly sown area during the first season of growth. Avoid walking or driving on it. Do not cut it unless it is very weedy in late June or early July, and then cut as high as possible. Most broad-leaved weeds can be controlled by spraying with 2,4-D.

\section{Seed Production}

Success in growing Russian wild ryegrass for seed depends on the following factors: seeding, fertilizing, irrigating, removing aftermath, harvesting, cleaning, and marketing.

\section{Seeding}

Establish seed production fields without using a nurse or companion crop because it reduces the seed yields of the grass for at least the first two years after seeding.

Highest yields have been obtained with row spacings of 2 feet or more (Table 2). At Swift Current the best yields were obtained when the grass was grown in 3- and 4-foot spacings. At Lacombe, Alberta, in a moister climate, the grass yielded best in 2 -foot spacings. As it is difficult to cultivate between rows in 2-foot spacings, a 3 -foot spacing is recommended for all locations (Figure 6).

Studies at Indian Head, Saskatchewan, showed that good seed crops can be produced when three closely spaced rows are alternated with a fallow strip 3 to 4 feet wide. The three rows provide a good place to lay the swath and the fallow strip ensures enough moisture to produce a crop of seed. 


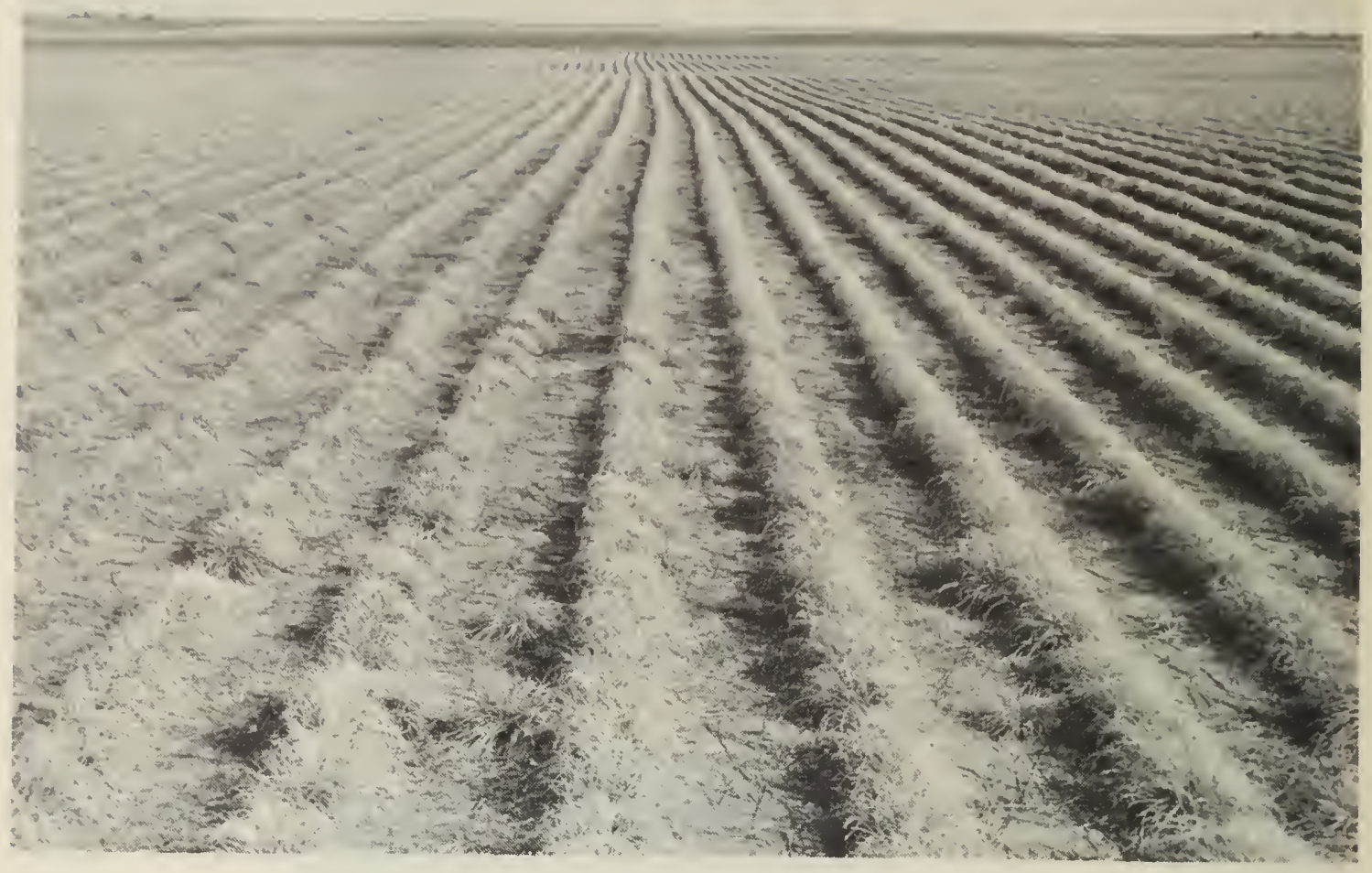

Figure 6 - A field of Russian wild ryegrass sown for seed production in rows 3 feet apart.

\section{Fertilizing}

Under average moisture conditions it pays to fertilize (Table 2).

\section{Table 2. Average Seed Yields of Russian Wild Ryegrass on Three Dryland Sites at Various Rates of 16-20-0 Fertilizer}

(Pounds per acre for rows 1 to 4 feet apart)

$\begin{array}{ccccc}\begin{array}{c}\text { Feet between } \\ \text { rows }\end{array} & \begin{array}{c}\text { Fertilizer } \\ \text { pounds per acre }\end{array} & \begin{array}{c}\text { Swift } \\ \text { Current } \\ 7 \text { years }\end{array} & \begin{array}{c}\text { Saskatoon } \\ \text { 4 years }\end{array} & \begin{array}{c}\text { Lacombe } \\ 5 \text { years }\end{array} \\ 1 & 0 & 23 & 101 & 216 \\ & 135 & 59 & - & 255 \\ 250 & 99 & - & 268 \\ 2 & 0 & 80 & - & 353 \\ & 135 & 138 & - & 417 \\ & 250 & 242 & - & 406 \\ 3 & 0 & 105 & 128 & 367 \\ & 135 & 165 & - & 367 \\ & 250 & 230 & - & 389 \\ 4 & 0 & 116 & - & 334 \\ & 135 & 208 & - & 359 \\ & 250 & 222 & - & 257\end{array}$


With heavy rates of fertilizer annually, good yields of seed can be obtained continuously for many years from a single seeding. In a 7-year test at Swift Current fertilizer increased the yields more as the stand aged.

The seed yields of Russian wild ryegrass, in pounds per acre, over a 7year period at Swift Current, sown in rows 3 feet apart and fertilized annually with $16-20-0$, were:

\section{Fertilizer}

$\begin{array}{ccccccrr}\text { lb. per acre } & 1 s t & 2 n d & 3 r d & 4 \text { th } & 5 \text { th } & 6 \text { th } & 7 \text { th } \\ 0 & 58 & 168 & 193 & 133 & 81 & 72 & 32 \\ 135 & 76 & 167 & 218 & 215 & 144 & 280 & 52 \\ 250 & 80 & 254 & 284 & 281 & 222 & 365 & 127\end{array}$

Evidently the soil nitrogen became progressively less available each year. The percentage increases for the 250-pounds per acre application from the first to the seventh year, respectively, were: $38,51,47,111,174,407$, and 297.

The time of fertilizer application is important also. At Swift Current, seed yields were twice as great from an August application as from a spring application at the same rate. At Lacombe, the early-fall application of fertilizer gave 16 percent higher seed yield than a similar one in the spring. Therefore, apply the fertilizer immediately after harvesting the seed crop.

The fertilizer required for good seed production depends on the soil. At Swift Current on loam soil, evidently phosphorus is not needed and the most economical fertilizer is ammonium nitrate $(33.5-0-0)$. The ammonium nitrate has twice as much nitrogen per pound as ammonium phosphate (16-20-0) and, pound for pound, it is cheaper. At present, the recommended fertilizer to apply for high seed production in the Brown and Dark Brown soil zones is ammonium nitrate at 100 to 150 pounds per acre. But, on Black soils, ammonium phosphate at 300 pounds per acre may give more economical results.

\section{Irrigating}

In dry years some growers obtain good seed yields by using water from sloughs, dugouts, or other sources for sprinkler irrigation. Although the timing of irrigation has not been studied extensively, observations suggest that this water can be used most economically by irrigating in August and again in early May. Where only one irrigation is possible, apply the water in early May. The 7-year average seed yields when two fertilizers were applied on irrigated plots at Pambrun, Saskatchewan, were: 
Fertilizer

Check

33. 5- $0-0$

33. $5-0-0$

$16-20-0$

$16-20-0$
Fertilizer lb./acre

None

75

150

150

300
(1955-61).

160

226

244

204

267

\section{Aftermath}

The leafy residue remaining after the seed has been harvested is nutritious and makes excellent feed for livestock. Experiments at Swift Current showed that removal of the aftermath forage is essential to maintain high seed yields. When sheep grazed the aftermath there was an increase in seed yield the following year. The sooner grazing commences after harvest, the greater the increase in seed yield (Figure 7). The grower who does not utilize the aftermath can expect lower seed yields and is wasting valuable pasture.

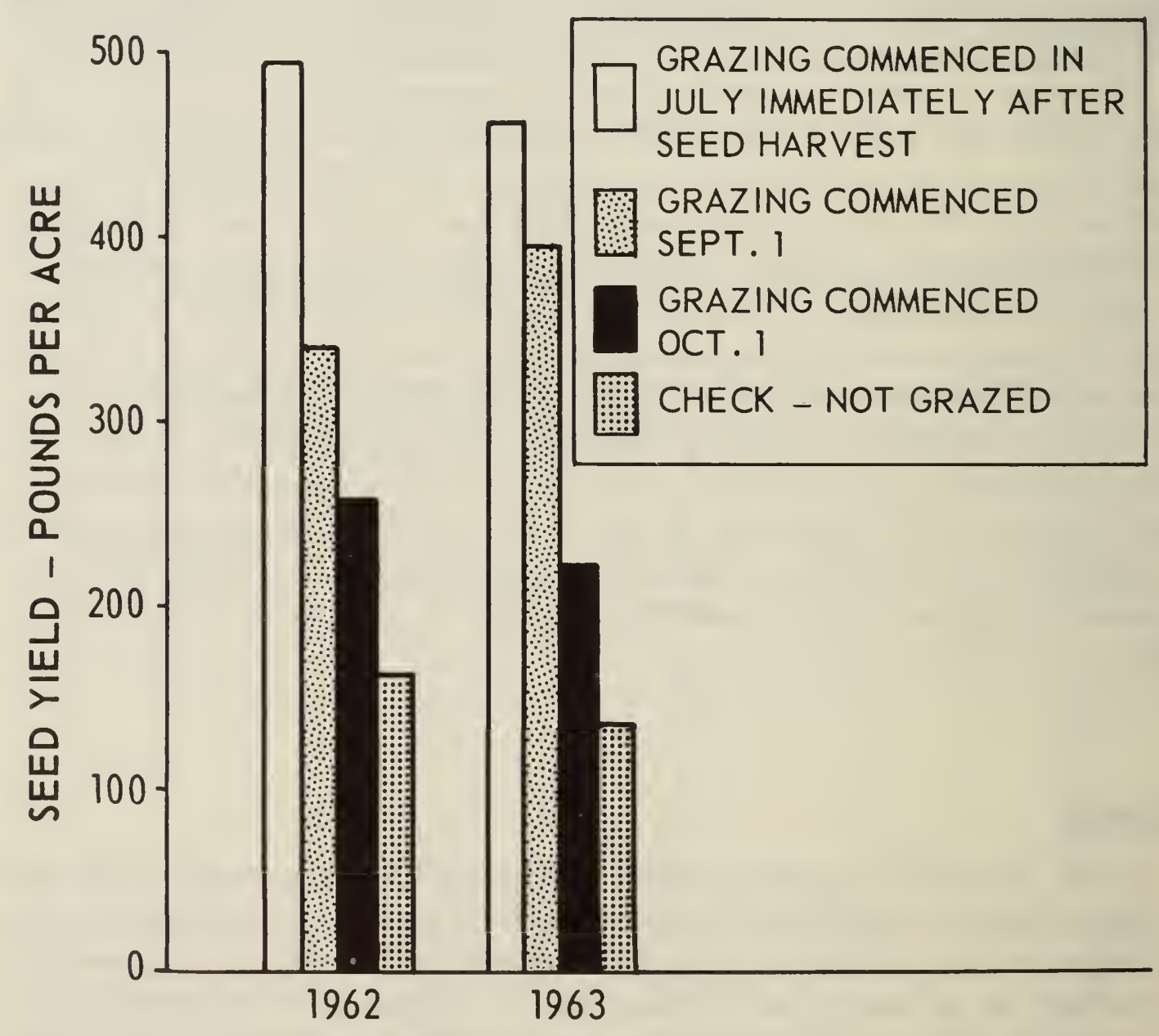

(YEAR OF HARVEST)

BIO.GRAPHIC UNIT - CA.NADA DEPT. OF AGRICULTURE

Figure 7 - Seed yields of Russian wild ryegrass in 1962 and 1963 as influenced by grazing after seed harvest during the preceding year. 


\section{Harvesting}

Russian wild ryegrass shatters its seed readily and must be cut before it is dead ripe. The best time to harvest is when the straw is golden yellow and the seed in the firm dough stage.

The best method of harvesting is to swath the crop just above the leafy basal growth and then thresh with a combine several days later (Figure 8). By this method the crop can be harvested at an earlier stage with much less loss in germination than when it is straight combined. If the crop is straight combined, good quality seed can be obtained in the 2 to 3 days before the seed shatters, and it must be dried artificially. Swathing and combining later allows harvesting to take place over a longer period, eliminates the need for artificial drying, and insures high germination. However, cutting more than 6 days before maturity will result in low kernel weight and lower yi eld.

Although swathing is the better method of harvesting, some difficulty has been experienced in picking up the swath when it falls between the rows. One grower has solved this problem by seeding the field at an angle, and swathing it by going around the field so that all swaths cross the rows at an angle. Another farmer arranged his field by seeding two rows one foot apart where the swath would fall; a self-propelled swather facilitated placing the swath on the double rows.

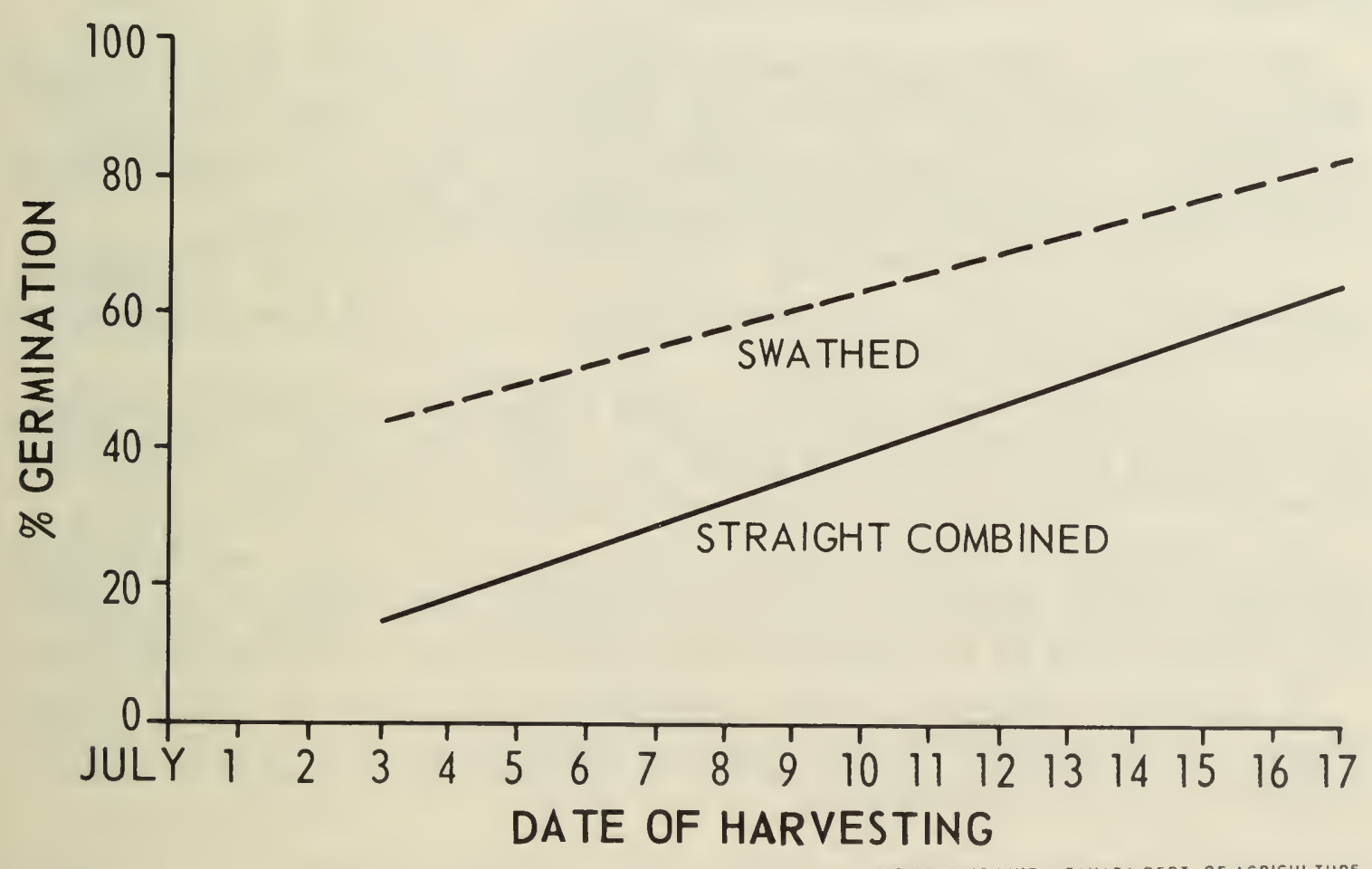

Figure 8 - Germination of Russian wild ryegrass seed when harvested by two methods on successive dates from July 3 to 17. 
Russian wild ryegrass can be threshed successfully with a combine. The rub-bar cylinder types are more suitable than the tooth cylinder types because they do not break up the straw so much. Correct combine adjustments come by trial and error and vary with the make of machine. The following suggestions may be helpful:

- At the start set the cylinder the same as for wheat. If the straw is broken too much, so that a great deal of it comes into the hopper with the seed, increase the clearance between the cylinder and the concaves. You may need to open up the cylinder as wide as possible. If this does not give the desired effect, slow the cylinder down slightly. Be careful not to slow it too much because this reduces the capacity of the combine and tends to plug it when large wads come in.

- Set the adjustable sieves $1 / 3$ to $1 / 2$ open. You can find the best setting only by repeated trials.

- To clean the seed properly slow down the fan as much as possible and adjust the wind control doors. Generally, shut the doors and with some machines insert pieces of cardboard to reduce the air intake.

- Direct the air blast toward the front of the sieves. This provides for better separation and avoids blowing seed over the back.

- You may have to slow down the operating speed of the pickup because high speed may cause excessive shattering and loss of seed.

\section{Cleaning}

The ordinary fanning mill usually cleans the seed well enough to seed through a drill but doesn't remove all weed seeds. An indent disc with appropriate discs is necessary to remove them. If you try to remove all weed seeds with the fanning mill, a lot of good grass seed may be lost.

Metal sheet screens are more suitable than wire screens for cleaning any grass seed. The wire screens plug up too easily and it is necessary to remove and clean them frequently.

Scalp the seed over a round-hole wheat or barley screen before cleaning. The scalping removes parts of heads and about 90 percent of the broken straw. A $15 / 64$ or $16 / 64$-inch round-hole screen is satisfactory.

For cleaning, a slotted screen $1 / 14 \times 1 / 4$ inch on top and $1 / 20$-inch round-hole at the bottom is usually satisfactory. Depending on the quality of the seed, it may be necessary to use screens larger or smaller than these.

If cleaning equipment is not available on the farm, the seed can be cleaned at a commercial seed cleaning plant. It is best to make the arrangements well before harvest.

\section{Marketing}

Most of the seed is sold to commercial seed houses. The seed is in good demand for local use and export, and most seed companies handle it. If you grow a large quantity of seed it is advisable to invest in cleaning machinery 
and clean the seed yourself. If you have a small quantity of seed it may be marketed through commercial seed houses in uncleaned form. There is a charge for cleaning the seed, and the dockage increases the cost of shipping.

Fifty-pound sacks are the easiest to handle; larger ones are awkward. Also, many sales are made in multiples of 50 pounds.

\section{ACKNOWLEDGMENTS}

Some of the information in this publication was supplied by the following officers of the Research Branch: R.P. Knowles, Saskatoon, Saskatchewan; E. Buglass, Indian Head, Saskatchewan; R.W. Peake, Lethbridge, Alberta; and A.T.H. Gross, Brandon, Manitoba.

\section{OTHER HELPFUL INFORMATION}

Campbell, J.B. 1961. Continuous versus repeated-seasonal grazing of grassalfalfa mixtures at Swift Current, Saskatchewan. J. Range Mgmt. 14: 72-77.

Campbell, J.B., R.W. Lodge, A. Johnston, and S. Smoliak. 1962. Range management of grasslands and adjacent parklands in the Prairie Provinces. Can. Dep. Agr. Pub. 1133.

Heinrichs, D.H., and R.B. Carson. 1956. Chemical composition of nine grasses at six stages of development. Can. J. Agr. Sci. 36: 95-106.

Kilcher, M.R., and D.H. Heinrichs. 1964. The comparative suitability of some grasses for turf in southern Saskatchewan. Can. J. Plant Sci. 44: 208-211.

Lawrence, T. 1960. Quality of Russian wild ryegrass seed as influenced by time and method of harvesting. Can. J. Plant Sci. 40: 474-481.

Lawrence, T. 1963. Seed yield of Russian wild ryegrass grown on an irrigated clay soil in southwestern Saskatchewan. J. Range Mgmt. 16: 311-312.

Lawrence, T., and J.E. Troelsen. 1964. An evaluation of 15 grass species as forage crops for southwestern Saskatchewan. Can. J. Plant Sci. 44: $301-310$.

Lawrence, T., and R. Ashford. 1964. Seed yield and morphological development of Russian wild ryegrass as influenced by grazing. Can. J. Plant Sci. 44: 311-317.

Lawrence, T., and R. Ashford. 1964. Russian wild ryegrass, a dual purpose crop. Research for Farmers. Vol. 9, No. 4: 8-9. (Can. Dep. Agr.).

Lawrence, T., and M.R. Kilcher. 1964. Effect of time of fertilizer application on the seed and forage yield of Russian wild ryegrass. J. Range Mgmt. 17: 272-273. 
Rauser, W.S., and W.L. Crowle, 1963. Salt tolerance of Russian wild ryegrass in relation to tall wheatgrass and slender wheatgrass. Can. J. Plant Sci. 43: 397-407.

Rogler, G.A., and H.N. Schaaf. 1963. Growing Russian wildrye in the Western States. U.S. Dep. Agr. Leaflet 524.

Stelfox, H.B., D.H. Heinrichs, and R.P. Knowles, 1954. Seed production studies with Russian wild-rye. Can. J. Agr. Sci. 34: 28-35.

Thaine, R. 1954. The effect of clipping frequency on the productivity and root development of Russian wild ryegrass in the field. Can. J. Agr. Sci. 34: 299-304.

Troelsen, J.E., and J.B. Campbell. 1959. Nutritional quality of forage crops adapted to southwestern Saskatchewan as determined by their digestibility and dry matter intake when fed to sheep. Can. J. Plant Sci. 39: 417-430. 


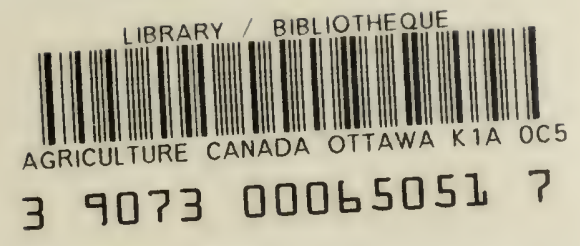


Copies of this publication may be obtained from: INFORMATION DIVISION

CANADA DEPARTMENT OF AGRICULTURE OTTAWA

First printed ................................ 1956

Reprinted ....................................... 1958

Revised ........................................ 1966 